\title{
PELATIHAN SISWA (i) DALAM PENGENALAN KONSEP LAMBANG BILANGAN DENGAN MENGGUNAKAN METODE MONTESSORI TEMA GO GREEN PADA PENDIDIKAN ANAK USIA DINI DI ALAM ISLAMIC RAINBOW SCHOOL LUWU TIMUR
}

\author{
Juwita Crestiani $\mathrm{M}^{1^{*}}$ \\ Opik Dwi Indah ${ }^{2}$ \\ Hermini $^{3}$ \\ 1,2,3 Universitas Cokroaminoto Palopo, Palopo, Indonesia \\ juwitacrestiani@uncp.ac.id ${ }^{\left.1^{*}\right)}$ \\ dwiindahopik@gmail.com ${ }^{2)}$ \\ miniparjas@gmail.com ${ }^{3}$ )
}

\author{
Kata Kunci: [Konsep \\ lambang bilangan, \\ Metode Montessori, Go \\ green]
}

https://dmi-journals.org/jai/

\begin{abstract}
Abstrak: Kegiatan pengabdian ini di adakan pada bulan awal bulan November 2020. Kegiatan ini sangat bermanfaat bagi anak usia dini karena mereka dapat mengasah kemampuan memahami makna konsep bilangan dengan indikator mencocokkan angka dengan media real object yaitu buah melalui kegiatan mencocokkan jumlah buah dengan lambang bilangan. Sehingga dapat melatih anak berhitung dengan menyebutkan angka satu, dua tiga dan seterusnya sekaligus mengenal lambang bilangan atau angkanya. Selain itu, semakin mengasah potensi dari aspek kognitif, bahasa dan social. Kegiatan pengabdian kepada masyarakat ini khususnya pada pendidikan anak usia dini di Alam Islamic Rainbow School di Wonorejo Timur Kab. Luwu Timur berupa pengenalan dan pengajaran lambang bilangan dengan mencocokkan dengan jumlah buahnya. Kegiatan pengabdian ini dilaksanakan selama 1 Minggu, dimana dalam pelaksanaannya terbagi dalam beberapa tahap yaitu: (1) tahap perencanaan (plan), (2) tahap pelaksanaan (do) dan (3) tahap evaluasi (see). Hasil dari kegiatan ini, siswa yang ikut dalam kegiatan ini merasa sangat senang dan antusias. Ini terlihat dari sikap yang mereka nampakkan dengan mengikuti kegiatan ini dari awal hingga akhir yaitu pada saat guru bertanya, siswa yang tahu jawabannya sangat antusias menjawab dan berulang kali mengangkat tangannya saat sesi pertanyaan secara massal atau menyeluruh. Salah satu media yang digunakan adalah real object yang ramah lingkungan dengan tema go green berupa buah-buahan. Hasil akhirnya adalah, seluruh anak usia dini dapat menepis rasa malu, raguragu mereka dengan berani menjawab pertanyaan dalam bentuk ujaran maupun ungkapan-ungkapan. Setelah kegiatan ini berakhir, diharapkan agar mereka dapat mengaplikasikan ilmu pengetahuan yang mereka dapatkan di dalam kehidupan sehari-hari.
\end{abstract}




\section{Pendahuluan}

Pendidikan memiliki posisi dan peranan penting dalam kehidupan dan proses pembangunan. Pendidikan bertujuan untuk meningkatkan kecerdasan generasi penerus bangsa dan agar tidak tertinggal dari bangsa yang maju lainnya. Anak usia dini merupakan usia yang efektif untuk mengembangkan berbagai potensi yang dimiliki anak.

Menurut NAEYC (National Assosiation Education for Young Children) dalam Sofia Hartati (2005: 7) anak usia dini merupakan sekelompok individu yang berada pada rentang usia antara 0-8 tahun. Sedangkan menurut Undang-undang Nomor 20 Tahun 2003 Pasal 1 angka 14 tentang Sistem Pendidikan Nasional dalam Permendiknas No 58 Tahun 2009 menyatakan bahwa;

\section{Pendidikan Anak Usia Dini (PAUD) adalah suatu upaya pembinaan yang ditujukan kepada anak sejak lahir sampai dengan usia enam tahun yang dilakukan melalui pemberian rangsangan pendidikan untuk membantu pertumbuhan dan perkembangan jasmani dan rohani agar anak memiliki kesiapan dalam memasuki pendidikan lebih lanjut.}

Montessori menjelaskan pada fase ini, pikiran anak masih mudah menyerap, tetapi kesadaran mulai muncul, hadirnya kesadaran ini diperoleh sebagian dari pengetahuan dan sebagian lagi dari bahasa (Britton, 2018:14).

Anak usia dini sering disebut dengan masa keemasan atau Golden Age. Pada masa keemasan ini diperlukan perhatian khusus karena anak peka belajar dan stimulasi yang diberikan dapat mempengaruhi perkembangan otak anak dan kemampuan akademiknya. Peran orang-orang terdekat terutama kedua orang tua baik dilingkungan rumah maupun sekolah amat penting bagi tumbuh dan berkembangnya potensi yang dimiliki anak. Kualitas lingkungan dan orang-orang terdekat anak berpengaruh besar terhadap kualitas nilai-nilai moral, nilai-nilai agama, perilaku, sosial emosional dan kemandirian, kognitif, berbahasa, fisik motorik dan daya cipta anak.

Kognitif merupakan salah satu aspek perkembangan anak yang perlu distimulasi pada usia dini. Pada usia empat tahun 50\% kecerdasan seseorang telah tercapai dan 80\% pada usia delapan tahun (Slamet Suyanto, 2005: 7). Pentingnya masa usia dini membuat guru dan orang tua perlu melakukan stimulasi agar perkembangan anak dapat optimal. Stimulasi pendidikan ini hendaknya dilakukan secara bertahap, berulang, konsisten, dan tuntas, sehingga memiliki daya ubah atau manfaat bagi anak. Seiring dengan bertambahnya usia, anak-anak membutuhkan rangsangan pendidikan yang lebih lengkap karena pada dasarnya semua anak itu cerdas.

Upaya pendidikan yang diberikan oleh pendidik hendaknya dilakukan dengan kegiatan yang menyenangkan yang menggunakan strategi, metode,materi/bahan, media yang menarik dan mudah dipahami peserta didik juga ramah lingkungan. Melalui kegiatan bermain peserta didik diajak untuk bereksplorasi menemukan dan memanfaatkan objek-objek yang dekat dengannya, sehingga pembelajaran jadi menyenangkan. Bermain merupakan kegiatan yang menyenangkan bagi anak karena dengan bermain anak dapat melakukan apa yang diinginkannya.

Permainan berhitung merupakan bagian dari matematika. Keterampilan berhitung sangat diperlukan dalam kehidupan sehari-hari, terutama konsep-konsep 
bilangan atau angka yang merupakan dasar bagi pengembangan kemampuan matematika maupun kesiapan untuk pendidikan dasar. Konsep angka melibatkan pemikiran tentang "berapa jumlahnya atau berapa banyak". Lambang bilangan atau angka perlu dikenalkan sebagai dasar bagi anak untuk berhitung. Caufield dalam Carol Seefeldt dan Barbara A Wasik (2008: 393) mengemukakan bahwa mempelajari nama yang sesuai dengan bilangan juga merupakan bagian dari belajar tata cara berhitung. Anak yang mempelajari nama bilangan kemudian akan mempelajari simbol dari bilangan tersebut. Menghitung selalu berhubungan dengan angka atau lambang bilangan. Lambang bilangan juga penting dikenal oleh seseorang karena banyak sekali benda-benda dalam kehidupan sehari-hari yang menggunakan angka seperti uang, jam, kalender, penggaris, timbangan, dan lainlain. Anak perlu mengenal lambang bilangan untuk memahami benda-benda tersebut.

Dari latar belakang tersebut, penulis tertarik melakukan dan memberi ilmu pengetahuan khususnya dalam pembelajaran matematika yaitu pelatihan pengenalan lambang bilangan pada pendidikan anak usia dini dengan metode Montessori yang ramah lingkungan.

Melalui kegiatan tersebut bertujuan dapat melatih anak berhitung dengan menyebutkan angka satu, dua tiga dan seterusnya sekaligus mengenal lambang bilangan atau angkanya. Tujuan lain yang juga melatarbelakangi diadakannya kegiatan ini adalah agar anak dapat mengembangkan potensinya sehingga mampu menguasai berbagai pengetahuan dan keterampilan matematika yang memungkinkan mereka untuk hidup dan bekerja pada masa mendatang yang menekankan pada kemampuan memecahkan masalah. Olehnya itu, kegiatan yang kami lakukan dalam bentuk pengabdian ini dapat memberikan gambaran bagaimana mengenalkan dan mengajarkan lambang bilangan.

Berdasarkan analisis situasi diatas, kendala yang dihadapi sebagian besar anak usia dini adalah strategi, metode juga media pembelajaran perlu digunakan secara terus menerus dengan pertimbangan utama bahwa media dapat mengkonkretkan sesuatu karena anak usia dini cenderung menyenangi sesuatu yang visual terlebih jika sangat menarik.

Berdasarkan indikator permasalahan yang dihadapi, maka dirumuskanlah sebuah permasalahan yang dihadapi anak usia dini di PAUD Alam Islmaic Rainbow School sebagai bentuk pengabdian kepada masyarkat yaitu langkah apa yang dilakukan dalam memberi pengenalan dan pengajaran lambang bilangan dengan metode Montessori pada pendidikan anak usia dini di PAUD Alam Islamic Rainbow School?

Kegiatan di sekolah Alam Islamic Rainbow School ini bertujuan untuk dapat melatih anak berhitung dengan menyebutkan angka satu, dua tiga dan seterusnya sekaligus mengenal lambang bilangan atau angkanya. Mereka mengasah kemampuan memahami makna konsep bilangan dengan indikator mencocokkan angka dengan media real object yaitu buah melalui kegiatan mencocokkan jumlah buah dengan lambang bilangan.

Tujuan lain yang juga melatarbelakangi diadakannya kegiatan ini adalah agar anak dapat mengembangkan potensinya sehingga mampu menguasai berbagai pengetahuan dan keterampilan matematika yang memungkinkan mereka untuk hidup dan bekerja pada masa mendatang yang menekankan pada kemampuan memecahkan masalah. 
Kegiatan pengabdian kepada masyarakat ini sangat bermanfaat bagi anak usia dini karena menstimulasi mereka berpikir dan memecahkan masalah atau menemukan jawaban. Selain itu, manfaat dari kegiatan ini adalah memberikan pengenalan, pembimbingan, pelatihan kepada anak usia dini mengenai pengenalan lambang bilangan yaitu berhitung yang didukung dengan bantuan media yang objectnya konkret dalam artian visual. Selain itu setelah mengikuti kegiatan ini, tentu saja diharapkan akan menambah semangat mereka dan tidak putus asa dalam belajar terutama belajar matematika yaitu berhitung. Kemudian, bagi dosen, kegiatan ini adalah merupakan upaya untuk melaksanakan salah satu bentuk dari Tri Darma Perguruan Tinggi yang bermanfaat dalam peningkatan dan pengembangan wawasan kemasyarakatan kalangan dosen, sehingga nantinya setelah selesainya kegiatan ini dapat terjalin komunikasi yang efektif dan produktif antara perguruan tinggi yang dalam hal ini adalah Dosen Universitas Cokroaminoto Palopo itu sendiri dengan masyarakat ruang lingkup PAUD Alam Islamic Rainbow School.

\section{Metode Pelaksanaan}

Kegiatan pengabdian ini dilaksanakan selama 1 minggu yang terbagi dalam beberapa tahap yaitu: (1) tahap perencanaan, (2) tahap pelaksanaan dan (3) tahap evaluasi. Pada tahap perencanaan telah ditetapkan hal-hal antara lain: tempat/ lokasi kegiatan yang dipilih yaitu di PAUD Alam Islamic Rainbow School terletak di Wonorejo, Luwu Timur. Jenis kegiatan berupa pengenalan dan pengajaran lambang bilangan. Tahap pelaksanaan berupa penyajian materi secara langsung tentang bilangan atau angka dengan sara pendukung yaitu media berupa real object yang ramah lingkungan berupa buah-buahan. Tahap yang terakhir adalah evaluasi akhir dan pelaporan. Kegiatan abdimas ini diikuti oleh siswa (i) PAUD dan juga guru-gurunya yang bertindak sebagai partner dosen.

Metode pelaksanaan kegiatan ini berupa pengenalan, pengajaran, pelatihan dan pembimbingan melalui ceramah, praktek dan tanya jawab dalam hal ini berupa evaluasi/koreksi mengenai pemahanam mereka terhadap materi. Adapun langkahlangkah yang dilakukan dalam pelaksanaan kegiatan ini adalah:

1. Ceramah digunakan untuk menyampaikan materi tentang lambang bilangan atau angka.

2. Pelatihan adalah tahapan yang paling utama dan sangat penting untuk dilakukan karena tahapan ini memberikan kesempatan bagi anak usia dini untuk mengasah dan mengembangkan potensi kognitif, bahasa dan social.

3. Evaluasi adalah tahap akhir yang digunakan untuk mengoreksi hasil pemahaman mereka terhadap materi.

Setelah dilaksanakannya kegiatan abdimas ini, diharapkan senantiasa terjalin komunikasi antara dosen, siswa (i) dan pihak sekolah PAUD agar kegiatan abdimas berikutnya dapat berjalan lebih optimal.

\section{Hasil dan Pembahasan}

Kegiatan pengabdian dengan tema go green untuk anak usia dini di Luwu Timur dilaksanakan pada hari Senin tanggal 09 November 2020 sampai hari Rabu tanggal 11 November 2020 di PAUD Alam Islamic Rainbow School. Kegiatan ini dimulai pukul 08.00 wita sampai pukul 12.00 wita. Target dari kegiatan ini adalah anak usia dini usia 5 tahun 
di PAUD Alam Islamic Rainbow School dan jumlah anak yang ikut dalam kegiatan ini adalah sebanyak 8 orang.

Dalam kegiatan awal kami selaku dosen memberikan penjelasan akan maksud kedatangan dan kegiatan kami. Dalam tahapan ini kami lebih memotivasi mereka bagaimana belajar matematika dengan cara belajar berhitung. Berhitung merupakan bagian dari matematika, diperlukan untuk menumbuh kembangkan keterampilan berhitung yang sangat diperlukan dalam kehidupan sehari-hari, terutama konsep-konsep bilangan yang merupakan dasar bagi pengembangan kemampuan matematika maupun kesiapan untuk pendidikan dasar.

Seluruh anak usia dini yang ikut dalam kegiatan ini terlihat sangat antusias dan senang walaupun masih ada yang terlihat malu-malu dan takut. Setelah itu mereka kemudian diberi kesempatan untuk mengenal lambang bilangan atau angka dengan cara berhitung. Mereka belajar mengenal lambang bilangan atau angka melalui real object yang sifatnya visual yaitu buah-buahan sebagai medianya. Mereka menghitung berapa jumlah buah kemudian jumlahnya di instruksikan untuk menunjukkan angka. Setiap anak usia dini akan di tanyai kembali mengenai materi yang telah di ajarkan. Selain itu setiap anak jalanan akan di instruksikan untuk mengulangi kembali apa yang di ucapkan oleh dosen terkait dengan materi. Kegiatan ini difokuskan potensi anak usia dini pada aspek kognitif yang dibarengi dengan aspek bahasa dan aspek sosial dimana terbagi kedalam beberapa tahapan yaitu kegiatan awal (bagaimana mengenal materi), kegiatan inti (bagaimana mengaplikasikannya ke dalam kehidupan sehari-hari) dan penutup (mengevaluasi pemahaman mereka). Setelah mereka selesai belajar berhitung kemudian dilakukan evaluasi.

\section{Kesimpulan}

Berdasarkan hasil kegiatan yang telah dilaksanakan, dapat disimpulkan bahwa kegiatan ini sangat bermanfaat bagi anak usia dini karena mereka dapat mengasah kemampuan memahami makna konsep bilangan dengan indikator mencocokkan angka dengan media real object yaitu buah melalui kegiatan mencocokkan jumlah buah dengan lambang bilangan.

Siswa (i) usia dini yang ikut dalam kegiatan ini merasa sangat senang dan antusias. Ini terlihat dari sikap yang mereka nampakkan dengan mengikuti kegiatan ini dari awal hingga akhir yaitu pada saat dosen bertanya, smereka yang tahu jawabannya sangat antusias menjawab dan berulang kali mengangkat tangannya saat sesi pertanyaan secara massal atau menyeluruh. Sehingga, hasil akhirnya adalah, seluruh anak usia dini dapat menepis rasa malu, ragu-ragu mereka dengan berani menjawab pertanyaan dalam bentuk ujaran maupun ungkapan-ungkapan. Siswa (i) semakin mengasah potensi dari aspek kognitif, bahasa dan social.

\section{Ucapan Terimakasih}

Kegiatan pengabdian ini dapat terselenggara berkat adanya kerja sama dan dukungan serta partisipasi dari berbagai pihak, olehnya itu kami ingin mengucapkan terima kasih banyak kepada kepala LPPM, Dr. Muhammad Ilyas, M.Pd., dekan FKIP, Dr. Rusdiana Junaid, M. Hum., M.A, Ibu Kepala PAUD Alam Islamic Rainbow School selaku mitra, guru PAUD Alam Islamic Rainbow School, seluruh pihak yang membantu dan berpartisipasi dalam kegiatan ini dan Universitas Cokroaminoto Palopo. 


\section{Referensi}

Britton, L. 2018. Montessori Play And Learn. Yogyakarta : Bentang Angkasa.

Depdiknas. (2009). Permendiknas No. 58 Tahun 2009 tentang Standar Pendidikan Anak Usia Dini. Jakarta: Departemen Pendidikan Nasional, Direktorat Jenderal Pendidikan Tinggi, Direktorat Pendidikan Tenaga Kependidikan dan Ketenagaan Perguruan Tinggi.

Seefeldt, Carol \& Wasik, Barbara A. (2008). Pendidikan Anak Usia Dini Menyiapkan Anak Usia Tiga, Empat, dan Lima Tahun Masuk Sekolah. (Alih Bahasa: Pius Nasar). Jakarta: PT Indeks.

Slamet Suyanto. (2005). Dasar-dasar Pendidikan Anak Usia Dini. Yogyakarta: Hikayat Publishing.

Sofia Hartati. (2005). Perkembangan Belajar pada Anak Usia Dini. Jakarta: Departemen Pendidikan Nasional, Direktorat Jenderal Pendidikan Tinggi, Direktorat Pendidikan Tenaga Kependidikan dan Ketenagaan Perguruan Tinggi. 